\title{
Recent Therapeutic Advances in Gastroenterology and Hepatology
}

\author{
Daniel E. Freedberg • Julian A. Abrams
}

To view enhanced content go to www.advancesintherapy.com

Published online: October 30, 2013

(C) The Author(s) 2013. This article is published with open access at Springerlink.com

Dear Colleague,

The past year has seen major therapeutic advances in gastroenterology and hepatology. Two areas with notable gains are related to infectious diseases: novel treatments directed against recurrent Clostridium difficile infection (CDI) and against the hepatitis $\mathrm{C}$ virus (HCV).

Clostridium difficile infection is an infectious colitis with high associated morbidity and mortality. Broad-spectrum antibiotics cause CDI by depleting the normal colonic flora and lowering barriers to $C$. difficile proliferation. Antibiotics directed against C. difficile (i.e., metronidazole and oral vancomycin) have a high initial success rate for CDI, but up to onethird of patients experience recurrence. Historically, recurrent CDI was treated with

D. E. Freedberg · J. A. Abrams ( $\square)$

Division of Digestive and Liver Diseases, Columbia

University Medical Center, 622 W 168th Street,

PH 7W 318, New York, NY 10032, USA

e-mail: ja660@cumc.columbia.edu

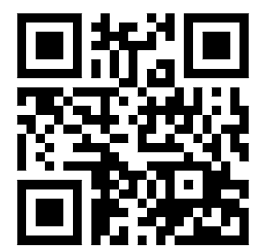

Enhanced content for Advances in Therapy articles is available on the journal web site: www.advancesintherapy.com extended, but often diminishingly effective courses of oral vancomycin [1]. But beginning in the 1980s, an alternative strategy was pursued: feces from a healthy donor was given via enema or colonoscopically to a diseased individual. Called fecal microbiota transplantation (FMT), this technique resulted in durable cure rates over 95\%, even among patients with multiple recurrences [2]. But there were problems with FMT. There was no randomized data supporting it, and the testing of donor stool for infectious microorganisms was not standardized. This changed in January 2013 with the results of a randomized study of oral vancomycin followed by FMT with pooled, pre-screened stool versus vancomycin alone. In this trial, $81 \%$ of the vancomycin-FMT group versus $27 \%$ of the vancomycin alone group experienced resolution of symptoms [3]. Subsequently, FMT has been expanded with studies demonstrating that donor stool can be collected, frozen, and administered later [4] or even impregnated in gel capsules and taken by mouth [5]. In the future, it is likely that specific organisms, selected to compete for resources against $C$. difficile, will replace FMT for treatment of recurrent CDI. 
The hepatitis $C$ virus is the most common cause of liver failure requiring transplantation in the developed world. Standard therapy for chronic HCV is with pegylated interferon alpha and ribavirin. Peginterferon must be given via weekly injections and, in combination with ribavirin, often has severe side effects including fatigue, depression, and anemia. Peginterferon-ribavirin given for 48 weeks has sustained virologic response (SVR) rates of $40-50 \%$ for $\mathrm{HCV}$ genotype 1 , the most common viral genotype in the USA [6]. In 2011, two new drugs were added to the arsenal against HCV: the protease inhibitors boceprevir and telaprevir. When combined with peginterferon-ribavirin, protease inhibitors improve SVR rates to $65-85 \%$ among genotype 1 patients, even when patients have previously responded to peginterferon, but have relapsed [7, 8]. However, treatment with protease inhibitors still requires peginterferon and is complicated by severe side effects including treatmentlimiting anemia in up to $50 \%$ of patients. But in 2013 interferon-free regimens emerged using a new class of drugs, HCV polymerase inhibitors $[9,10]$. In one study, patients with untreated HCV genotype 1 received an all-oral regimen consisting of a protease inhibitor, a polymerase inhibitor, and ribavirin and achieved SVR rates of $52-69 \%$ after just 12 weeks of treatment [11]. Significant anemia and other severe adverse events were rare $(<10 \%)$, suggesting that the regimen will be appropriate for HCV genotype 1 patients who cannot tolerate interferon. Several similar, equally promising regimens are in phase 2 or 3 studies, so patients with HCV can expect to have multiple all-oral treatment options.

The recent progress in CDI and HCV has been encouraging and we expect further therapeutic advances in these areas in 2014.
Daniel E. Freedberg

Julian A. Abrams

\section{OPEN ACCESS}

This article is distributed under the terms of the Creative Commons Attribution Noncommercial License which permits any noncommercial use, distribution, and reproduction in any medium, provided the original author(s) and the source are credited.

\section{REFERENCES}

1. Dupont HL. Diagnosis and management of Clostridium difficile infection. Clin Gastroenterol Hepatol. 2013;11(10):1216-23.

2. Brandt LJ, Aroniadis OC, Mellow M, Kanatzar A, Kelly C, Park T, et al. Long-term follow-up of colonoscopic fecal microbiota transplant for recurrent Clostridium difficile infection. Am J Gastroenterol. 2012;107(7):1079-87.

3. van Nood E, Vrieze A, Nieuwdorp M, Fuentes S, Zoetendal EG, de Vos WM, et al. Duodenal infusion of donor feces for recurrent Clostridium difficile. $\mathrm{N}$ Engl J Med. 2013;368(5):407-15.

4. Hamilton MJ, Weingarden AR, Sadowsky MJ, Khoruts A. Standardized frozen preparation for transplantation of fecal microbiota for recurrent Clostridium difficile infection. Am J Gastroenterol. 2012;107(5):761-7.

5. Louie T. Fecal microbiome transplantation via oral fecal microbial capsules for recurrent Clostridium difficile infection. IDweek 2013; abstract 89.

6. Liang TJ, Ghany MG. Current and future therapies for hepatitis $\mathrm{C}$ virus infection. $\mathrm{N}$ Engl J Med. 2013;368(20):1907-17.

7. Jacobson IM, McHutchison JG, Dusheiko G, Di Bisceglie AM, Reddy KR, Bzowej NH, et al. Telaprevir for previously untreated chronic hepatitis $\mathrm{C}$ virus infection. $\mathrm{N}$ Engl $\mathrm{J}$ Med. 2011;364(25):2405-16.

8. Poordad F, McCone J Jr, Bacon BR, Bruno S, Manns $\mathrm{MP}$, Sulkowski MS, et al. Boceprevir for untreated chronic HCV genotype 1 infection. N Engl J Med. 2011;364(13):1195-206. 
9. Gane EJ, Stedman CA, Hyland RH, Ding X, Svarovskaia E, Symonds WT, et al. Nucleotide polymerase inhibitor sofosbuvir plus ribavirin for hepatitis C. N Engl J Med. 2013;368(1):34-44.

10. Poordad F, Lawitz E, Kowdley KV, Cohen DE, Podsadecki T, Siggelkow S, et al. Exploratory study of oral combination antiviral therapy for hepatitis C. N Engl J Med. 2013;368(1):45-53.

11. Zeuzem S, Soriano V, Asselah T, Bronowicki JP, Lohse AW, Mullhaupt B, et al. Faldaprevir and deleobuvir for HCV genotype 1 infection. N Engl J Med. 2013;369(7):630-9. 